\title{
PENERAPAN MODEL PEMBELAJARAN MASTERY LEARNING DALAM MENINGKATAN HASIL BELAJAR IPA PADA PESERTA DIDIK KELAS IX.3 SMP NEGERI 32 PALEMBANG
}

\author{
Luli Afrita \\ Guru SMP Negeri 32 Palembang \\ afrita_luli@gmail.com
}

\begin{abstract}
Abstrak
Permasalahan mendasar dalam penelitian ini adalah sebagian besar peserta didik kelas IX.3 SMP Negeri 32 Palembang kurang memahami Pewarisan sifat. Bertitik tolak dari uraian di atas, maka dirumuskan masalah dalam penelitian ini yaitu yang menjadi rumusan masalah dalam penelitian ini adalah: "Bagaimanakah peningkatan hasil belajar IPA setelah diterapkannya model pembelajaran Mastery Learning pada peserta didik kelas IX.3 SMP Negeri 32 Palembang?". Tujuan yang diharapkan dari penelitian ini adalah untuk mengetahui peningkatan hasil belajar IPA setelah diterapkan model pembelajaran Mastery Learning pada peserta didik kelas IX.3 SMP Negeri 32 Palembang. Subjek dalam penelitian ini adalah peserta didik Kelas IX.3 SMP Negeri 32 Palembang yang berjumlah 32 peserta didik. Penelitian ini akan dilaksanakan pada semester ganjil di kelas IX.3 SMP 32 Palembang pada bulan Agustus s/d Oktober tahun 2019. Penelitian tindakan kelas ini telah dikatakan tuntas dengan dibuktikannya peningkatan hasil belajar IPA menggunakan model pembelajaran Mastery Learning. Ketuntasan belajar meningkat dari Pra siklus, siklus I ke siklus II yaitu masing-masing 46.88\%, 59,38\% dan 90,63 \% Pada siklus II ketuntasan belajar peserta didik secara klasikal telah tercapai dan mengalami peningkatan yang sangat baik.
\end{abstract}

Kata Kunci: Hasil Belajar, IPA, Mastery Learning

\begin{abstract}
The basic problem in this research is that most of the class IX.3 students of SMP Negeri 32 Palembang do not understand the inheritance of traits. Starting from the description above, the problem formulated in this study is that the problem formulation in this study is: "How is the increase in science learning outcomes after the implementation of the Mastery Learning learning model in class IX.3 students of SMP Negeri 32 Palembang?". The expected goal of this research is to find out the increase in science learning outcomes after the Mastery Learning learning model is applied to class IX.3 students of SMP Negeri 32 Palembang. The subjects in this study were students of Class IX.3 SMP Negeri 32 Palembang, totaling 32 students. This research will be carried out in the odd semester in class IX.3 SMP 32 Palembang in August to October 2019. This classroom action research has been said to be complete with the evidence of increasing science learning outcomes using the Mastery Learning learning model. Mastery learning increased from pre-cycle, cycle I to cycle II, which were 46.88\%, 59.38\% and 90.63\%, respectively. In cycle II, students' learning mastery classically had been achieved and experienced a very good increase.
\end{abstract}

Keywords: Learning Outcomes, Science, Mastery Learning 


\section{PENDAHULUAN}

Pendidikan sangat berguna dalam kehidupan manusia. Menurut Agus Taufiq, dkk (2011: 1.3) pendidikan setidak-tidaknya memiliki ciri sebagai berikut: (1) Pendidikan merupakan proses mengembangkan kemampuan, sikap, dan bentuk-bentuk tingkah laku lainnya di dalam masyarakat, dimana dia hidup, (2) Pendidikan merupakan proses sosial, dimana seseorang dihadapkan pada pengaruh lingkungan yang terpilih dan terkontrol (khususnya yang datang dari sekolah) untuk mencapai kompetensi sosial dan pertumbuhan individual secara optimum, (3) Pendidikan merupakan proses pengembangan pribadi atau watak manusia.

IPA merupakan ilmu pengetahuan yang mempelajari tentang alam beserta isinya baik makhluk hidup maupun tak hidup. Jadi mata pelajaran IPA di SMP merupakan IPA terpadu yang objek kajiannya sangat luas mencakup alam beserta isinya serta segala gejala yang terjadi didalamnya. Harus disadari oleh para guru bahwa pada dasarnya tujuan pembelajaran yang harus dicapai siswa dalam suatu kegiatan pembelajaran IPA harus dapat menggambarkan atau mencakup tujuan pembelajaran IPA. Apabila ditelaah ternyata tujuan pelajaran IPA tidak hanya kepada pencapaian akademik namun lebih banyak nilai-nilai non akademik. Maka dari itu kegiatan pembelajaran IPA bukan hanya menekankan pada hasil akan tetapi juga pada proses.

Proses belajar mengajar merupakan bagian dari kegiatan guru di sekolah. Proses belajar mengajar atau yang sering disebut dengan PBM berguna untuk menyampaikan informasi, pengetahuan, pengalaman kepada peserta didik. Kenyataan yang ada pada saat ini bahwa dalam komunikasi sering terjadi penyimpangan sehingga proses belajar mengajar menjadi tidak efektif dan efisien. Keadaan tersebut disebabkan oleh beberapa hal diantaranya: ada kecenderungan verbalisme, ketidaksiapan peserta didik, kurang minat peserta didik, kurangnya sarana dan prasarana pembelajaran

Pendidikan sekolah dasar terdapat beberapa mata pelajaran yang harus dikuasai siswa. Salah satunya adalah Ilmu Pengetahuan Alam (IPA). IPA merupakan konsep pembelajaran alam dan mempunyai hubungan yang sangat luas terkait dengan kehidupan 
manusia. Proses pembelajaran IPA memberikan pengalaman langsung kepada siswa untuk memahami alam sekitar secara ilmiah. Tujuan pembelajaran IPA di SMP adalah agar siswa dapat mempelajari diri sendiri dan alam sekitar serta dapat mengembangkan pengetahuan dan pamahaman konsep - konsep IPA yang bermanfaat dan dapat diterapkan dalam kehidupan sehari hari.

Sebagian siswa menganggap mata pelajaran IPA sebagai mata pelajaran yang sulit dipahami sehingga siswa cenderung merasa bosan, jenuh dan malas untuk belajar, siswa kurang termotivasi karena menganggap mata pelajaran IPA merupakan mata pelajaran yang membutuhkan pemahaman konsep yang luas. Aktivitas siswa yang rendah dapat mempengaruhi hasil belajar siswa.

Berdasarkan temuan hasil ulangan harian di kelas IX.3 SMP Negeri 32 Palembang di temukan hasil ulangan yang masih rendah. Target KKM yang haru di capai oleh peserta didik adalah nilai 65 dapat di katakan tuntas. Hasil ulangan IPA Terpadu belum bisa di katakan berhasil karena dalam 32 peserta didik yang mengikuti ulangan harian IPA Terpadu terdapat
17 peserta didik yang belum mencapai ketuntasan yang di harapkan KKM 65 dan hanya 15 peserta didik yang mampu melewati nilai KKM.

Beranjak dari rendah nya nilai hasil ulangan harian IPA Terpadu kelas IX.3 SMP Negeri 32 Palembang disebakan antara lain sebagai berikut; Peserta didik masih banyak yang mengobrol dengan teman sebangku. Peserta didik tidak bertanya apabila ada kesulitan dalam belajar. Guru kurang memperhatikan peserta didik yang belum mengerti.Guru masih kurang menggunakan model pembelajaran yang tepat dalam proses belajar mengajar yang masih konvensional yang berfokus kepada guru

Maka dari itu perlunya sebuah sikap dari guru untuk meningkatkan hasil belajar IPA Terpadu kelas IX.3 SMP Negeri 32 Palembang sehingga permasalahan tidak berlarut terlalu lama. Peserta didik bisa lebih aktif dan semangat dalam mengikutiti pembelajaran IPA Terpadu.

Berdasarkan latar belakang di atas, adapun rumusan masalah dalam penelitian ini adalah : " Apakah Penerapan Model Pembelajaran Mastery Learning Pada Peserta Didik 
Kelas IX.3 SMP Negeri 32 Palembang dapat meningkatan Hasil Belajar IPA Terpadu?".

Sesuai dengan rumusan masalah di atas, maka penelitian ini bertujuan untuk mengetahui peningkatan hasil belajar IPA Terpadu setelah diterapkan model pembelajaran Mastery Learning pada peserta didik kelas IX.3 SMP Negeri 32 Palembang.

Menurut Hamalik (2011:55) dalam bukunya berjudul Kurikulum dan pembelajaran "pembelajaran adalah suatu kombinasi yang tersusun meliputi unsur-unsur manusiawi, material, fasilitas, perlengkapan dan prosedur yang saling mempengaruhi dalam mencapai tujuan pembelajaran". Selain itu, pembelajaran merupakan suatu sistem yang terdiri dari berbagai komponen yang saling berhubungan satu dengan yang lain. Komponen tersebut meliputi tujuan, materi, metode, dan evaluasi, dan keempat komponen tersebut harus diperhatikan oleh guru dalam memilih dan menentukan pendekatan, dan modelmodel pembelajaran apa yang akan digunakan dalam kegiatan pembelajaran (Rusman, 2013:379).

Selanjutnya, menurut Slameto (2010:3) menyatakan hasil belajar sebagai perubahan yang terjadi dalam diri seseorang berlangsung secara berkesinambungan, tidak statis. Satu perubahan yang terjadi akan menyebabkan perubahan berikutnya dan akan berguna bagi kehidupan ataupun proses belajar berikutnya. Hasil belajar yang dicapai peserta didik dipengaruhi dua faktor utama yakni faktor lingkungan dan faktor yang datang dari diripeserta didikitu sendiri terutama kemampuan yang dimilikinya. Dari beberapa pendapat dapat disimpulkan bahwa hasil belajar merupakan hasil akhir yang diperoleh peserta didik setelah proses belajar mengajar terjadi.

Sudjana (2001:22) memandang bahwa hasil belajar adalah kemampuan-kemampuan yang dimiliki siswa setelah menerima pengalaman belajarnya. Pengalaman belajar di dapat siswa setelah melalui proses belajar mengajar. Proses adalah kegiatan yang dilakukan oleh siswa dalam mencapai tujuan pengajaran.

IPA merupakan kumpulan pengetahuan yang diperoleh tidak hanya produk saja tetapi juga mencakup pengetahuan seperti ketrampilan dalam hal melaksanakan penyelidikan ilmiah. Proses ilmiah 
yang dimaksud misalnya melalui dan ilmunya selalu berkembang juga pengamatan, eksperimen, dan analisis menjadi tumpuan bagi perkembangan yang bersifat rasional, sedang sikap IPTEK. Sehingga matapelajaran IPA ilmiah misalnya objektif dan jujur menuntut siswa untuk dapat berpikir dalam mengumpulkan data yang kritis guna mengembangkan sikap yang diperoleh. Dengan menggunakan kreatif dalam memecahkan masalah proses dan sikap ilmiah tersebut yang ada dikehidupan sehari-hari. memperoleh penemuan-penemuan atau Terutama pada siswa SMP mereka produk yang berupa fakta, konsep, perlu dipelajari mengenai IPA karena prinsip, dan teori.

Hakikat Ilmu Pengetahuan mereka akan tumbuh dan berkembang di masyarakat nantinya.

Alam (IPA) menurut Trianto (2013: Model belajar tuntas (Mastery 137), IPA dibangun atas dasarproduk, Learning) adalah pencapaian taraf ilmiah, proses ilmiah, sikap ilmiah dan nilai yang terdapat didalamnya. penguasaan minimal yang ditetapkan untuk setiap unit bahan pelajaran baik Wahyana (dalam Trianto, 2013: 136), IPA adalah suatu kumpulan tersusun secara sistematik, dan dalam penggunaannya secara umum terbatas pada gejala-gejala alam. Susanto secara perseorangan maupun kelompok, dengan kata lain apa yang dipelajari siswa dapat dikuasai sepenuhnya .(Usman.1993:96)

Mastery learning merupakan (2013: 167), Hakikat pembelajaran IPA dapat diklasifikasikan dalam tiga bagian yaitu ilmu pengetahuan alam sebagai produk, proses dan sikap.

IPA merupakan salah satu dasar ilmu pengetahuan dan juga menjadi tumpuan bagi perkembangan iptek (Ratna Hidayat dan Pratiwa Pujiastuti, 2016: 186). Jadi dapat disimpulkan hakikat IPA adalah kumpulan teori yang mempelajari alam semesta, lahir dan berkembang melalui metode ilmiah suatu pendekatan pembelajaran yang menganut azas ketuntasan belajar. Belajar tuntas (Mastery Learning) adalah pendekatan pembelajaran berdasar pandangan filosofis bahwa seluruh peserta didik dapat belajar jika mereka mendapat dukungan kondisi yang tepat. Konsep belajar tuntas adalah proses belajar yang bertujuan agar bahan ajaran dikuasai secara tuntas, artinya cara menguasai materi secara penuh. Belajar tuntas ini 
merupakan strategi pembelajaran yang di individualisasikan dengan menggunakan pendekatan kelompok.

Dengan sistem belajar tuntas diharapkan proses belajar mengajar dapat dilaksanakan agar tujuan instruksional yang akan dicapai dapat diperoleh secara optimal sehingga proses belajar lebih efektif dan efisien. (Sukmadinata \& Nana Syaodih. 2005:24)

Model belajar tuntas ini terdiri atas lima tahap, yaitu orientasi (orientation), penyajian (presentation), latihan terstruktur (structured practice), latihan terbimbing (guided practice) dan latihan mandiri (independent practice). Tujuan proses belajar mengajar secara ideal adalah agar bahan yang dipelajari dikuasai sepenuhnya oleh peserta didik. Ini disebut mastery learning atau belajar tuntas, artinya penguasaan penuh (Nasution.2011:36)

Menurut

Carol

(dalam

Made.2009) setiap peserta didik akan mampu menguasai bahan kalau diberikan waktu dan kesempatan yang cukup untuk mempelajarinya sesuai dengan kapasitas masing-masing peserta didik. Dengan demikian, taraf atau tingkatan belajar itu pada dasarnya merupakan fungsi dari proporsi waktu yang disediakan untuk belajar, dengan waktu yang diperlukan untuk belajar. Carol tidak menyangkal bahwa ada faktor dominan lain yang berpengaruh terhadap taraf penguasaan belajar itu, yaitu antara kualitas pengajaran dengan taraf kemampuan peserta didik untuk memahami pelajaran itu. Selain itu, faktor motivasi juga sangat berpengaruh.

Karena itu, kalau guru menghendaki peserta didik mencapai penguasaan bahan pelajaran tertentu, maka bahan harus disusun secara sempurna begitu juga instrumen evaluasi atau pengukuran hasil belajarnya. Bahan pelajaran harus diperinci dan diorganisasikan ke dalam satuan-satuan (unit) tertentu sampai kepada satuan-satuan terkecil yang bermakna dan merupakan bagian yang tidak dipisahkan dari satuan yang lebih besar.

\section{METODE}

Penelitian ini termasuk jenis penelitian tindakan kelas (PTK), dengan ciri utamanya adalah adanya tindakan yang berulang dan metode utamanya adalah refleksi diri yang bertujuan untuk memperbaiki pembelajaran. 
Menurut Arikunto (2006) 2019 s.d November 2019. Subjek menyatakan bahwa penelitian tindakan dalam penelitian ini adalah siswa kelas kelas dapat dilaksanakan melalui empat IX.3 SMP Negeri 32 Palembang tahun langkah utama yaitu perencanaan, ajaran 2019/2020 dengan jumlah tindakan, observasi, dan refleksi. peserta didik 32 siswa. Subjek Empat langkah utama yang saling penelitian ini sangat heterogen dilihat berkaitan itu dalam pelaksanaan dari kemampuannya, yakni ada penelitian tindakan kelas sering disebut sebagian peserta didik yang dengan istilah 1 (satu) siklus. Keempat mempunyai kemampuan tinggi, langkah tersebut membentuk sebuah sedang, dan rendah.

siklus yang beruntun dan selanjutnya Alasan peneliti menggunkan kembali ke langkah semula. peserta didik kelas IX.3 SMP Negeri Banyaknya siklus dalam penelitian 32 Palembang sebagai subjek tindakan kelas tidak dibatasi secara penelitian, karena berdasarkan hasil pasti.

Penelitian akan dilaksanakan observasi pada saat pembelajaran guru hanya menggunakan metode ceramah pada siswa kelas IX.3 SMP Negeri 32 dan peserta didik tidak dilibatkan Palembang tahun ajaran 2019/2020. Alasan peneliti memilih lokasi di kelas IX.3 SMP Negeri 32 Palembang ini dikarenakan adanya relasi sehingga dalam aktivitas belajar. Selain itu, adanya permasalahan yang dihadapi oleh guru di sekolah tersebut yaitu mengenai hasil belajar peserta didik dapat bekerja sama dengan kepala sekolah dan guru kelas yang yang masih rendah, sehingga peneliti tertarik untuk melakukan penelitian bersangkutan, sehingga peneliti tertarik untuk melakukan penelitian. Penentuan tempat ini diharapkan memberi kemudahan khususnya menyangkut kebiasaan yang dilakukan dalam lingkungannya yang berhubungan dengan siawa sebagai objek

Penelitian ini di laksanakan pada semester ganjil bulan September dan beranggapan bahwa kelas IX.3 dalam pembelajaran ini guru harus pandai menggunakan model yang tepat agar hasil belajar peserta didik dapat tercapai dengan optimal.

Adapun indikator yang diharapkan dalam kegiatan penelitian ini adalah: Terjadi peningkatan hasil belajar yaitu di atas KKM 65 peserta 
didik tuntas belajar IPA Terpadu dan sebanyak $85 \%$ peserta didik mencapai ketuntasan belajar secara klasikal.

Untuk mengetahui keefektivan suatu metode dalam kegiatan pembelajaran perlu diadakan analisa data. Pada penelitian ini menggunakan teknik analisis deskriptif kualitatif, yaitu suatu metode penelitian yang bersifat menggambarkan kenyataan atau fakta sesuai dengan data yang diperoleh dengan tujuan untuk mengetahui hasil belajar yang dicapai peserta didik juga untuk memperoleh respon peserta didik terhadap kegiatan pembelajaran serta aktivitas peserta didik selama proses pembelajaran.

Untuk mengalisis tingkat keberhasilan atau persentase keberhasilan peserta didik setelah proses belajar mengajar setiap putarannya dilakukan dengan cara memberikan evaluasi berupa soal tes tertulis pada setiap akhir putaran.

\section{HASIL PENELITIAN}

\section{Siklus I}

Tindakan siklus I dilaksanakan dua kali pertemuan. Pertemuan pertama dilaksanakan pada hari Rabu, tanggal 11 September 2019 dan pertemuan kedua pada hari Rabu tanggal 18 September 2019. Berdasarkan hasil belajar pada siklus I dapat di lihat pada table di bawah ini.

Tabel 1 Hasil belajar Siklus I

\begin{tabular}{ll}
\hline Jumlah Nilai & $=\mathbf{2 1 3 0}$ \\
\hline $\begin{array}{l}\text { Jumlah Nilai } \\
\text { Maksimal ideal }\end{array}$ & $=\mathbf{3 2 0 0}$ \\
\hline $\begin{array}{l}\text { Rata-rata Nilai } \\
\text { Tercapai }\end{array}$ & $=\mathbf{6 6 . 5 6}$ \\
\hline $\begin{array}{l}\text { Jumlah siswa yang } \\
\text { belum tuntas }\end{array}$ & $=\mathbf{1 3}$ \\
\hline $\begin{array}{l}\text { Jumlah siswa yang } \\
\text { tuntas }\end{array}$ & $=\mathbf{1 9}$ \\
\hline $\begin{array}{l}\text { Persentase } \\
\text { Belum tuntas }\end{array}$ & $=\mathbf{4 0 . 6 3}$ \\
\hline $\begin{array}{l}\text { Persentase } \\
\text { ketuntasan }\end{array}$ & $=\mathbf{5 9 . 3 8}$ \\
\hline Klasikal & $=\begin{array}{l}\text { Belum } \\
\text { Tuntas }\end{array}$ \\
\hline
\end{tabular}

Bedasarkan table diatas dapat di jelaskan bahwa hasil belajar siklus I di kelas IX.3 SMP Negeri 32 Palembang terdapat nilai rata- rata 66.56. Siswa yang mendapatkan nilai ketuntasan sebanyak 19 peserta didik dengan jumlah persentase $59.38 \%$. Sedangkan peserta didik yang belum tuntas yakni 13 peserta didik dengan persentase $40.63 \%$. Maka sesuai target ketuntasan yang telah di tetapkan peneliti,pada siklus I belum mencapai ketuntasan secara keseluruhan,karena terdapat 13 dari 32 peserta didik dengan persentase $40.63 \%$ belum mencapai KKM yang telah di tetapkan yakni sebesar $85 \%$ ketuntasan secara keseluruhan. Jadi 
perlu nya perbaikan pada siklus pembelajaran Mastery Learning. berikutnya.

Penguasaan kelas perlu ditingkatkan Proses keberhasilan dengan cara memberikan teguran pembelajaran IPA memahami materi terhadap siswa yang ribut. Guru Pewarisan sifat dengan menerapkan kurang memberikan kesempatan pembelajaran Model Pembelajaran kepada siswa untuk memberikan kesan Mastery Learning yang dilakukan oleh mengenai pembelajaran yang telah guru dapat dilihat dari lembar dilakukan.

observasi. Berdasarkan pembelajaran

Siklus II

yang dilaksanakan pada siklus I oleh

Pelaksanaan tindakan siklus II pengamat, terlihat bahwa beberapa dilakukan dua kali pertemuan yaitu aspek yang telah dicapai dengan baik pada hari Rabu, tanggal 25 September antara lain: Guru melakukan proses 2019 pukul 10.00-11.45 WIB dengan pembelajaran sesuai dengan rencana jumlah 32 orang, dan pertemuan kedua pelaksanaan pembelajaran dengan baik.

Rabu tanggal 2 Oktober 2019 dimulai Guru menerapkan pembelajaran pukul 10.00-11.45 WIB dengan berbasis masalah pada menulis jumlah 32 orang. Pelaksanaan argumentasi dengan baik. Siswa pembelajaran dilaksanakan dengan dengan bimbingan guru menulis tiga tahap, yaitu kegiatan kembali hasil dari penyuntingan pendahuluan, kegiatan inti, dan dengan baik.

Adapun kelemahan-kelemahan kegiatan penutup.

Pengamatan pada siklus II sama yang harus diperbaiki pada siklus I dengan siklus I. Selama kegiatan yang dilakukan observer antara lain: berlangsung, observer melakukan Pemberian apersepsi atau motivasi observasi untuk melihat tindakanperlu ditingkatkan agar siswa tindakan guru dan aktivitas siswa semangat untuk belajar. Menjelaskan saat proses pembelajaran memahami tujuan pembelajaran agar siswa materi melalui model pembelajaran tertarik untuk mengikuti Mastery Learning. Berdasarkan hasil pembelajaran. Guru terburu-terburu observasi didapatkan bahwa proses dalam memberikan penjelasan belajar mengajar yang berlangsung mengenai materi dengan model 
sudah jauh lebih baik dari pada pelaksanaan kegiatan pada siklus I.

Tabel 2 Hasil belajar siklus II

\begin{tabular}{ll}
\hline Jumlah Nilai & $=\mathbf{2 3 3 0}$ \\
\hline $\begin{array}{l}\text { Jumlah Nilai } \\
\text { Maksimal ideal }\end{array}$ & $=\mathbf{3 2 0 0}$ \\
\hline $\begin{array}{l}\text { Rata-rata Nilai } \\
\text { Tercapai }\end{array}$ & $=\mathbf{7 2 . 8 1}$ \\
\hline $\begin{array}{l}\text { Jumlah siswa yang } \\
\text { belum tuntas }\end{array}$ & $=\mathbf{3}$ \\
\hline $\begin{array}{l}\text { Jumlah siswa yang } \\
\text { tuntas }\end{array}$ & $=\mathbf{2 9}$ \\
\hline $\begin{array}{l}\text { Persentase } \\
\text { Belum tuntas }\end{array}$ & $\mathbf{9 . 3 8}$ \\
\hline $\begin{array}{l}\text { Persentase } \\
\text { ketuntasan }\end{array}$ & $\mathbf{9 0 . 6 3}$ \\
\hline Klasikal & $=$ Tuntas \\
\hline
\end{tabular}

Bedasarkan table diatas dapat di jelaskan bahwa hasil belajar siklus II di kelas IX.3 SMP Negeri 32 Palembang terdapat nilai rata- rata 72.58.Siswa yang mendapatkan nilai ketuntasan sebanyak 29 peserta didik dengan jumlah persentase $90.63 \%$. Sedangkan peserta didik yang belum tuntas yakni 3 peserta didik dengan persentase 9.38 $\%$. Maka sesuai target ketuntasan yang telah di tetapkan peneliti,pada siklus II telah mencapai ketuntasan secara keseluruhan,karena terdapat 29 dari 32 peserta didik dengan persentase 90.63 $\%$. Jadi tidak perlu di lanjutkan ke siklus berikutnya.

Berdasarkan hasil analisis observasi aktivitas guru pada siklus II, ada beberapa aspek yang sebelumnya pada siklus I masih kategori kurang baik, dan pada siklus II sudah menjadi kategori baik, yaitu sebagai berikut: Guru telah memberikan apersepsi kepada siswa.Guru menjelaskan prosedur pembelajaran dengan baik. Guru memberikan penjelasan mengenai materi. Guru membimbing siswa saat diskusi kelompok, guru mengarahkan membimbing siswa agar tetap fokus pada permasalahan yang dibahas.Guru telah menguasai kelas dengan baik pada saat siswa ribut guru memberikan teguran kepada siswa. Pada saat kegiatan penyuntingan hasil pekerjaan siswa, guru membimbing siswa dengan memberikan penguatan menyampaikan kesan terhadap pembelajaran.

Berdasarkan hasil refleksi di atas dapat dikatakan bahwa aktivitas guru pada siklus II secara keseluruhan sudah mencapai semua Indikator yang telah ditetapkan pada lembar observasi.Namun demikian, pembelajaran dengan menerapkan model pembelajaran Mastery Learning ini perlu ditingkatkan dan dipertahankan. 


\section{Pembahasan}

Hasil penilaian dari observasi pada siklus II hasil penilaian dan observasi pada siklus II pada pembelajaran IPA Tepadu pada siswa kelas IX.3 SMP Negeri 32 Palembang sudah mengalami peningkatan yang sangat baik. Sikap siswa dalam mengikuti kegiatan pembelajaran materi pewarisan sifat dengan menggunakan Model Pembelajaran Mastery Learning mengalami perubahan ke arah yang positif. Hal ini dikarenakan guru berhasil membangkitkan gairah belajar siswa, sehingga siswa termotivasi untuk belajar. Selain itu, pada siklus II guru memberikan topik mengenai penyalahgunaan jejaring sosial lebih membuat siswa dengan jelas mengutarakan argumen dengan alasan yang beragam. Hal ini menunjukkan bahwa pembelajaran melalui model pembelajaran Mastery Learning merupakan cara yang sangat baik untuk meningkatkan keterampilan siswa berargumentasi. Peningkatan hasil tes belajar dapat dilihat pada tabel berikut ini:
Tabel 3 Pembahasan Hasil Belajar

\begin{tabular}{cccc}
\hline $\begin{array}{l}\text { Proses } \\
\text { Pembela } \\
\text { jaran }\end{array}$ & $\begin{array}{c}\text { Persentase } \\
\text { Ketuntasan }\end{array}$ & $\begin{array}{c}\text { Jumlah } \\
\text { Ketuntas } \\
\text { an }\end{array}$ & $\begin{array}{c}\text { Nilai } \\
\text { Rata } \\
\text { Rata }\end{array}$ \\
\hline $\begin{array}{c}\text { Pra } \\
\text { Siklus }\end{array}$ & 46.88 & 15 & 65.06 \\
\hline Siklus I & 59.38 & 19 & 66.56 \\
\hline Siklus II & 90.63 & 29 & 72.58 \\
\hline
\end{tabular}

Dari tabel tersebut dapat dilihat bahwa rata-rata nilai tes siswa pada pra siklus 65.06. Nilai rata-rata hasil belajar siklus I adalah 66.56. Pada siklus I siswa yang memperoleh nilai tertinggi dari 80 siswa, sedangkan nilai terendah dengan nilai 50 .Pada siklus II nilai rata-rata nilai tes siswa adalah 72,58. Pada siklus II siswa yang memperoleh nilai tertinggi dari 32 siswa yang mengikuti tes adalah nilai 80 , sedangkan nilai terendah dengan nilai 55. Hasil tes ini sudah cukup memuaskan, karena terjadi peningkatan siklus II (90.63). Jumlah persentase daya serap pada siklus 1 adalah $59.38 \%$. Pada siklus II persentase daya serap siswa mengalami peningkatan sebesar menjadi 90,63\%. Artinya, siswa sudah memahami secara baik materi pelajaran yang diajarkan dan siswa dapat belajar argumentasi dengan baik. Data tersebut 
menunjukkan bahwa terjadinya Peningkatan-peningkatan yang cukup peningkatan pada setiap siklus. baik tersebut disebabkan kelemahanKetuntasan belajar diperoleh kelemahan pada siklus I berhasil memenuhi kriteria bahkan dapat diperbaiki pada siklus II. Pada dikategorikan memuaskan, sebab peningkatan aktivitas siswa tentu saja kriteria ketuntasan minimum (KKM) dipengaruhi oleh faktor kemampuan secara klasikal SMP Negeri 32 guru dalam menjelaskan dan Palembang adalah 65 dan yang dicapai membimbing proses belajar IPA pada siklus II tersebut melebihi standar melalui model pembelajaran Mastery minimum 85\%. Walaupun pada siklus Learning di kelas IX.3 SMP Negeri 32 I ketuntasan belajar siswa secara Palembang.

klasikal belum memuaskan, tetapi pada

\section{KESIMPULAN}

siklus II ketuntasan belajar secara

Berdasarkan hasil penelitian dari klasikal sudah memuaskan, karena siklus I dan II, dapat disimpulkan sudah mencapai target yang telah ditetapkan yaitu $85 \%$ siswa mendapatkan nilai 65 ke atas. Peningkatan hasil belajar pra siklus,siklus 1 dan siklus II dapat dilihat pada grafik di bawah ini:

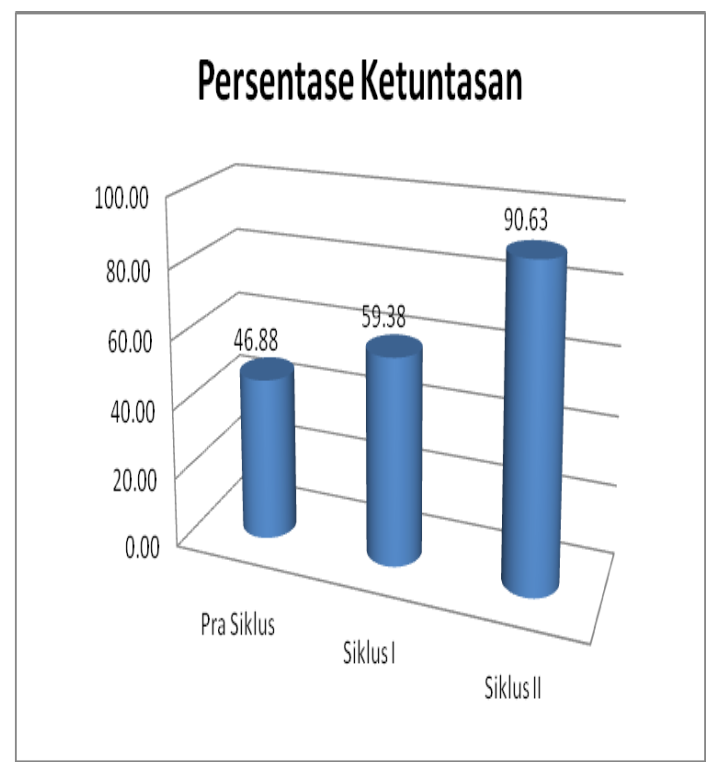
bahwa pembelajaran IPA Terpadu melalui Model Pembelajaran Mastery Learning dapat meningkatkan hasil belajar siswa kelas IX.3 SMP Negeri 32 Palembang tahun ajaran 2019-2020. Melalui model pembelajaran Mastery Learning pada pembelajaran IPA Terpadu yang pertama siswa masih terlihat tidak aktif dalam mengikuti pembelajaran. Namun, pada siklus kedua aktivitas belajar siswa terlihat menjadi lebih aktif hal ini dikarenakan guru menjelaskan model pembelajaran Mastery Learning pada pembelajaran IPA dengan pelan-pelan sehingga siswa menjadi paham dengan tugas yang diberikan.

Grafik 1 Pembahasan hasil belajar 


\section{DAFTAR PUSTAKA}

Ahmad Susanto. 2013. Teori Belajar dan Pembelajaran di Sekolah Dasar. Jakarta: Kencana Prenadamedia Group

Arikunto. Suharsimi. 2006. Prosedur Penelitian Suatu Pendekatan Praktik. Jakarta: PT. Rineka Cipta

Hamalik, Oemar. 2011. Kurikulum dan Pembelajaran. Jakarta: Bumi Aksara

Hidayah, Ratna dan Pratiwi Pujiastuti. .2016. "Pengaruh PBL Terhadap Keterampilan Proses Sains dan Hasil Belajar Kognitif IPA Pada Siswa SD". Jurnal Prima Edukasia. Vol 4, No. 2, halaman 186-197. Yogyakarta.

Made Alit Mariana.2003. Pembelajaran Remedial. Jakarta: Depdiknas

Moh. User Usman. 1993. Upaya Optimalisasi Kegiatan Belajar Mengajar. Bandung: PT Remaja Rosdakarya,

Nasution. 2011. Berbagai Pendekatan dalam Proses Belajar Mengajar.Jakarta: PT Bumi Aksara.

Rusman. 2013. Model-Model Pembelajaran:Mengembangkan Profesionalisme Guru. Ed. 2. Jakarta: Rajawali Pers.

Slameto. 2010. Belajar dan FaktorFaktor Yang Mempengaruhi. Jakarta: PT. Rieneka Cipta
Sudjana. 2001. Metode \& Teknik Pembelajaran Partisipatif. Bandung : Falah Production.

Sukmadinata \& Nana Syaodih. 2005.Landasan Psikologi Proses Pendidikan.PT. Remaja Rosdakarya: Jakarta.

Trianto.2013. Mendesain Model Pembelajaran Inovatif, Progresif, Konsep, Landasan, dan Implementasinya Pada Kurikulum Tingkat Satuan Pendidikan (KTSP). Jakarta: Kencana Prenada Media Group. 